\title{
Development and Validation of a Sensitive and Rugged LC-MS/MS Method for Evaluation of Valganciclovir and its Active Metabolite Ganciclovir in Human Plasma
}

\author{
V. R. DERANGULA ${ }^{1}$, M. R. TALLURI*, V. PONNERI², S. R. POLAGANI AND V. ADIREDDY \\ ACR Laboratories, Ramanthapur, Hyderabad-500 013, ${ }^{1}$ Research Studies, Rayalaseema University, Kurnool-518 002 , \\ ${ }^{2}$ Analytical and Environmental Chemistry Division, Department of Chemistry, Sri Venkateswara University, Tirupati-517 502, \\ India
}

Derangula et al.: A Sensitive and Rugged LC-MS/MS Method for Evaluation of Valganciclovir

\begin{abstract}
The current study was aimed to develop and validate a simple and sensitive method to quantify valganciclovir and its metabolite ganciclovir in human plasma using valganciclovir-D5, ganciclovir-D5 as internal standards for pharmacokinetic analyses. The method exhibited highly sensitive ranges $2-805 \mathrm{ng} / \mathrm{ml}$ for valganciclovir and $40-12000 \mathrm{ng} / \mathrm{ml}$ for ganciclovir. The analytes were extracted from plasma using solid phase extraction employing mixed-mode cation exchange cartridges. Valganciclovir and ganciclovir were separated using Agilent XDB-Phenyl column with a mobile phase consisting 35:65 ratio of $10 \mathrm{mM}$ ammonium acetate in $0.3 \%$ formic acid and acetonitrile at $0.60 \mathrm{ml} / \mathrm{min}$ flow rate with $2.50 \mathrm{~min}$ run time. The validated parameters were within the acceptance criteria as per the regulatory guidelines and the validated calibration curve ranges to both analytes have $r$ value $>0.99$ with above $90 \%$ recovery. The validated method was successfully used to study pharmacokinetics of orally administered valganciclovir $(900 \mathrm{mg})$ in healthy male volunteers. The pharmacokinetic parameters were, $C_{\max } 300 \mathrm{ng} / \mathrm{ml}$ for valganciclovir and $6000 \mathrm{ng} / \mathrm{ml}$ for ganciclovir, and $t_{\max }$ $0.50 \mathrm{~h}$ for valganciclovir and $1.00 \mathrm{~h}$ for ganciclovir.
\end{abstract}

Key words: Valganciclovir, ganciclovir, plasma, metabolite, deuterated, recovery, pharmacokinetics

The discovery and development of new drugs involved many vital processes such as drug identification, isolation, synthesis and analysis ${ }^{[1]}$. The analysis part is most important and very difficult for new drugs because, the results indicate their purity, quantification and interpretation of these data play key role in identification and estimation of their pharmacological activity $^{[2,3]}$. In last few decades, several new diseases have emerged like Ebola and some diseases have become untreatable ${ }^{[4,5]}$. This situation prompted the researchers to discover new drugs and new analytical methods to identify accurately with reliable certainty ${ }^{[6]}$. In the present-day viral infections fall under this situation, because these affect epidemically and pandemically the population around the world ${ }^{[7,8]}$.

Valganciclovir (VAL) is one of the antiviral drug to treat the cytomegalovirus (CMV) infections in acquired immune deficiency syndrome (AIDS) patients for retinitis and in organ transplantation condition to prevent $\mathrm{CMV}$ infections ${ }^{[9,10]}$. VAL is a prodrug for ganciclovir (GAN), which is an analogue

*Address for correspondence E-mail: tmrao1987@gmail.com

July-August 2019 for 2'-deoxyguanosine and the deoxyribonucleic acid (DNA) synthesis is terminated by inhibiting the DNA polymerase enzyme in CMV by replacing the 2' deoxyguanosine triphosphate ${ }^{[11-14]}$. The World Health Organization (WHO) added VAL as essential medicine as an effective and safe medicine needed for human wealth ${ }^{[15]}$. Recently, US FDA approved the manufacturing of generic VAL but the available analytical methods for VAL are not suitable to quantify in different biological matrices. There are some early reports on bio-analytical methods for VAL, GAN but, they are old, were analysed with nondeuterated drugs as internal standards (IS) and are not sensitive ${ }^{[16-19]}$. The high accuracy results are very important in quantification of drugs using IS through

This is an open access article distributed under the terms of the Creative Commons Attribution-NonCommercial-ShareAlike 3.0 License, which allows others to remix, tweak, and build upon the work non-commercially, as long as the author is credited and the new creations are licensed under the identical terms

Accepted 23 June 2019

Revised 28 March 2019

Received 25 December 2018

Indian J Pharm Sci 2019;81(4):747-756 
liquid chromatography with tandem mass spectrometry (LC-MS-MS), use of stable isotope labelled ISs usage provides the accurate results and reduces the variations in $\mathrm{MS}^{[20,21]}$. So, the current study was aimed to develop new bio-analytical method with deuterated drugs as IS for VAL and GAN in human plasma and its validation as per regulatory guidelines (US FDA).

\section{MATERIALS AND METHODS}

The solvents used in the current investigation were LCMS grade (J.T. Baker, USA). Analytical grade formic acid (98-100 \%) was from Merck (Mumbai, India). Standard VAL, GAN, GAN D5 were procured from Vivan Life Sciences (Mumbai, India) and VAL D5 was procured from Clear Synth Labs (Mumbai, India). The human plasma with K2 EDTA as anticoagulant was obtained from Deccan Pathological Laboratory (Hyderabad, India). The LC-MS-MS used was equipped with an LC system from Shimadzu (Japan) and API-4000 MS-MS from Sciex (USA); XDB Phenyl $4.6 \times 75 \mathrm{~mm}$ (Make- Agilent) column was used.

\section{Standard and internal standard stock solution:}

VAL stock solution $(1 \mathrm{mg} / \mathrm{ml})$ was prepared in methanol and GAN, GAN D5, VAL D5 were also prepared as $1 \mathrm{mg} / \mathrm{ml}$ solutions in dimethyl sulphoxide. These stock solutions were used for further dilutions with $50 \%$ acetonitrile (ACN) in HPLC grade water (diluent) to prepare calibration curve and quality control (QC) samples. The calibration curve points were ten nonzero concentrations with range $2.04-805.35 \mathrm{ng} / \mathrm{ml}$ for VAL and 40.41-12097.57 ng/ml for GAN and QCs were $2.05 \mathrm{ng} / \mathrm{ml}$ (lower limit of quantification quality control, LLOQ QC), $6.01 \mathrm{ng} / \mathrm{ml}$ (lower quality control, LQC), $125.28 \mathrm{ng} / \mathrm{ml}$ (middle quality control 1, MQC1),
$377.35 \mathrm{ng} / \mathrm{ml}$ (middle quality control 2, MQC2), and $566.56 \mathrm{ng} / \mathrm{ml}$ (high quality control, HQC) for VAL and $40.43 \mathrm{ng} / \mathrm{ml}$ (LLOQ QC), $121.04 \mathrm{ng} / \mathrm{ml}$ (LQC), $1806.56 \mathrm{ng} / \mathrm{ml}$ (MQC1), $6021.89 \mathrm{ng} / \mathrm{ml}$ (MQC2), and $9041.88 \mathrm{ng} / \mathrm{ml}$ (HQC) for GAN as final concentrations in blank plasma spiked as $5 \%$ from 20 times working concentrations prepared with diluent using standard stock solutions. Dilution integrity (DI) samples were prepared by spiking 3.10 times $(2495.07 \mathrm{ng} / \mathrm{ml}$ of VAL and 3.16 times of $38205.11 \mathrm{ng} / \mathrm{ml}$ of GAN) of the highest standard concentration. These spiked samples were stored at $-70^{\circ}$ and 12 sets of LQC and HQC at $-20^{\circ}$ for further validation study.

\section{LC-MS/MS method optimization:}

The separation and quantification of VAL and GAN were carried out using LC-MS/MS with positive and negative ionization modes, finally fixed to positive ion mode with different mass optimization parameters such as the curtain gas (CUR) and collision energy (CE) for VAL and GAN. The final optimized parameters for mass spectrometry are shown in Table 1 . Separation of the two analyte from the same sample is always difficult using LC at different concentrations of analytes but VAL and GAN were separated successfully with good response even at low concentrations. The optimized chromatographic conditions are listed in Table 2.

\section{Sample preparation:}

The solid phase extraction (SPE) method was used to extract the drugs from plasma samples. About $250 \mu 1$ of the plasma sample was pipetted into pre-labelled RIA vials, which contained $25 \mu 1$ of ISs dilution (from working concentrations, $5000 \mathrm{ng} / \mathrm{ml}$ of VAL D5 and $10000 \mathrm{ng} / \mathrm{ml}$ of GAN D5), except in blank plasma

TABLE 1: OPTIMIZED MASS SPECTROMETRY PARAMETERS

\begin{tabular}{|c|c|c|c|c|}
\hline Parameter & Valganciclovir & Valganciclovir D5 & Ganciclovir & Ganciclovir D5 \\
\hline Detection $(\mathrm{m} / \mathrm{z})$ & $\begin{array}{c}355.10 \text { (parent) and } \\
152.10 \text { (product) }\end{array}$ & $\begin{array}{c}360.10 \text { (parent) and } \\
152.10 \text { (product) }\end{array}$ & $\begin{array}{l}256.10 \text { (parent) and } \\
152.10 \text { (product) }\end{array}$ & $\begin{array}{c}261.10 \text { (parent) } \\
\text { and } 152.10 \\
\text { (product) }\end{array}$ \\
\hline Ion spray voltage (IS) & $5500.00 \mathrm{~V}$ & $5500.00 \mathrm{~V}$ & $5500.00 \mathrm{~V}$ & $5500.00 \mathrm{~V}$ \\
\hline Temperature $\left({ }^{\circ}\right)$ & 550.00 & 550.00 & 550.00 & 550.00 \\
\hline Curtain gas (CUR) & 25.00 psi & 25.00 psi & 25.00 psi & 25.00 psi \\
\hline Collision gas (CAD) & 6.00 psi & 6.00 psi & 6.00 psi & 6.00 psi \\
\hline GS1 & 30.00 psi & 30.00 psi & 30.00 psi & 30.00 psi \\
\hline GS2 & 35.00 psi & 35.00 psi & 35.00 psi & 35.00 psi \\
\hline Declustering potential (DP) & $70.00 \mathrm{~V}$ & $70.00 \mathrm{~V}$ & $90.00 \mathrm{~V}$ & $66.00 \mathrm{~V}$ \\
\hline Collision energy (CE) & $28.00 \mathrm{~V}$ & $28.00 \mathrm{~V}$ & $21.00 \mathrm{~V}$ & $22.00 \mathrm{~V}$ \\
\hline Collision cell exit potential (CXP) & $12.00 \mathrm{~V}$ & $10.00 \mathrm{~V}$ & $10.00 \mathrm{~V}$ & $10.00 \mathrm{~V}$ \\
\hline Entrance potential (EP) & $10.00 \mathrm{~V}$ & $10.00 \mathrm{~V}$ & $10.00 \mathrm{~V}$ & $10.00 \mathrm{~V}$ \\
\hline Dwell time (ms) & 200 & 200 & 200 & 200 \\
\hline
\end{tabular}


TABLE 2: OPTIMIZED LIQUID CHROMATOGRAPHY PARAMETERS

\begin{tabular}{|c|c|}
\hline Column & XDB Phenyl 4.6×75 mm (make-Agilent) \\
\hline Rinsing solution & Acetonitrile and water (50:50 \% v/v) \\
\hline Mobile phase & $\begin{array}{c}\text { LCMS grade acetonitrile: } 10 \mathrm{mM} \\
\text { ammonium acetate in } 0.3 \% \text { formic } \\
\text { acid }(65: 35, \mathrm{v} / \mathrm{v})\end{array}$ \\
\hline Flow rate & $0.600 \mathrm{ml} / \mathrm{min}$ \\
\hline $\begin{array}{l}\text { Sample cooler } \\
\text { temperature }\end{array}$ & $5^{\circ}$ \\
\hline $\begin{array}{l}\text { Column oven } \\
\text { Temperature }\end{array}$ & $40^{\circ}$ \\
\hline Injection volume & $10 \mu \mathrm{l}$ \\
\hline $\begin{array}{l}\text { Retention time } \\
\text { (RT) }\end{array}$ & $\begin{array}{c}\text { Valganciclovir } 1.67 \pm 0.5 \mathrm{~min} \\
\text { Valganciclovir D5 } 1.67 \pm 0.5 \mathrm{~min} \\
\text { Ganciclovir } 1.60 \pm 0.5 \mathrm{~min} \\
\text { Ganciclovir D5 } 1.60 \pm 0.5 \mathrm{~min}\end{array}$ \\
\hline Run time & $2.50 \mathrm{~min}$ \\
\hline
\end{tabular}

samples where $25 \mu 1$ diluent was added and then samples were vortexed. Then, $200 \mu 1$ of $2 \%$ orthophosphoric acid (OPA) buffer was added and vortexed. The sample mixture was loaded onto Strata ${ }^{\mathrm{TM}}-\mathrm{X}-\mathrm{C}, 33 \mu$ strong cation cartridges $(30 \mathrm{mg} / \mathrm{ml})$, pre-conditioned with $1.0 \mathrm{ml}$ methanol, followed by $1.0 \mathrm{ml}$ water. After applying maximum pressure, the extraction cartridge was washed with $1.0 \mathrm{ml}$ of $2 \%$ OPA buffer and followed by $1.0 \mathrm{ml}$ of $5 \%$ methanol in water. Then, the sample was eluted with $1.0 \mathrm{ml}$ of $5 \%$ ammonia in methanol. The samples were the evaporated to dryness at $50^{\circ}$ in turbo evaporator under nitrogen gas and reconstituted the residue with $500 \mu 1$ of mobile phase and vortexed. The reconstituted samples were centrifuged at $4000 \mathrm{rpm}$ at $4^{\circ}$ for $5 \mathrm{~min}$ and transferred into vials and loaded on to the auto sampler.

\section{Method validation:}

The developed method for quantification of VAL and GAN was validated as per USFDA guidelines ${ }^{[22]}$. The method validation included determination of sensitivity, selectivity, matrix effect (ME), linearity, accuracy, precision, recovery, DI, run size evaluation (RSE) and stability (room temperature, RT $\left(20 \pm 5^{\circ}\right)$ stock solution stability, refrigerated stock solution stability at $2-8^{\circ}$, freeze-thaw stability, bench top stability, short-term plasma samples stability at $20 \pm 5^{\circ}$, wet extract stability at $20 \pm 5^{\circ}$ and auto sampler stability (AS).

The sensitivity was measured to check back noise by spiking 6 LLOQ QC samples. Ten lots of blank plasma samples including lipemic and haemolytic were used for selectivity and ME was checked. Linearity was checked with in the concentration range of 2.04 to $805.35 \mathrm{ng} / \mathrm{ml}$ for VAL and $40.41 \mathrm{ng} / \mathrm{ml}$ to $12097.57 \mathrm{ng} / \mathrm{ml}$ for GAN with 6 replicates of 5 different QC samples (LLOQ, LQC, MQC1, MQC2 and HQC). Precision was measured with percent coefficient of variance using concentrations of QC samples. Accuracy was expressed in percent for an absolute ratio of the mean value of calculated concentration of LLOQ, LQC, MQC1, MQC2 and HQC samples to their nominal values. Recovery of VAL, GAN and their ISs were determined by comparing the areas of extracted 6 replicates at LQC, MQC2 and HQC levels with post spiking blank plasma. The DI was performed with 3.10 times of VAL $(2495.07 \mathrm{ng} / \mathrm{ml})$ and 3.16 times of GAN (38205.11 ng/ml) for 4 times dilution. The RSE was performed with 40 sets of each LQC, MQC1, MQC2 and HQC with freshly prepared CCs and six sets of QCs.

Stability is very important in quantification of any drugs in aqueous or in different biological matrices. Stability studies for VAL and GAN in the developed method were carried out at different conditions; re-injection stability was checked for retention of already injected samples stability in auto sampler, AS was checked for the retention of processed samples, which were kept in auto sampler for analysis, wet extract stability was carried to know the stability of processed samples at RT, bench-top stability was carried to express the stability of drugs in spiked plasma after thawing, shortterm stability was carried to know the stability of drugs in spiked plasma at $-20^{\circ}$ because usually spiked plasma samples were stored at $-70^{\circ}$, whole blood stability was studied to check the stability of drug in blood at RT and freeze-thaw stability was done to provide the number of freeze-thaw cycles for processing of spiked plasma.

\section{Data processing:}

Analyst 1.6.3 software was used for the chromatograms were acquired and processed by peak area ratio. The concentration of the unknown was calculated from the following Eqn. using regression analysis of spiked standard with the reciprocal of the square of ratio of the drug concentration to internal standard concentration as a weighting factor $(1 /$ concentration ratio $) \times 2, y=m x+c$, where, $y$ is peak area ratio of VAL and GAN to IS; $m$ is the slope of the calibration curve, $\mathrm{x}$ is the concentration of VAL and GAN ( $\mathrm{ng} / \mathrm{ml})$, and c is y-axis intercept of the calibration curve.

\section{Clinical application:}

The developed and validated method was applied in a clinical study on 6 healthy volunteers for 
pharmacokinetic study by giving $900 \mathrm{mg}$ of oral solution dosage $(50 \mathrm{mg} / \mathrm{ml})$ as approved by ethical committee (MAARG Independent Ethics Committee, Hyderabad). The study conducted on fasting conditions and blood samples (6 $\mathrm{ml}$ at each time-point) were collected in $\mathrm{K} 2$ EDTA vacutainer collection tubes (BD franklin, NJ, USA) at pre-dose $(0 \mathrm{~h}), 0.167,0.33,0.50,0.67,0.83$, $1.0,1.25,1.50,1.75,2.0,2.25,2.50,2.75,3.0,3.33$, $3.67,4.0,4.5,5.0,6.0,8.0,10.0,12.014 .0,16.0,24.0$ and $36.0 \mathrm{~h}$. After collection, sample were centrifuged at $4000 \mathrm{rpm}$ for $5 \mathrm{~min}$ and then plasma samples were immediately stored at $-70 \pm 10^{\circ}$ for further use. These samples were analysed as unknown samples along with validated CC ranges of VAL, GAN and QCs as known samples. WinNonlin Professional software version 6.4 was used to calculate pharmacokinetic parameters of the samples. After sample analysis incurred, sample reanalysis (ISR) was carried out to verify the reliability of validated method.

\section{RESULTS AND DISCUSSION}

Method development involved the detection of ions of VAL, GAN and their ISs using mass spectrometry, separation using LC and extraction of VAL and GAN from plasma using SPE. Before finalizing the above mentioned mass optimized parameters (Table 1), both the drugs were monitored under positive and negative ionization modes, a good response was observed under positive ionization mode, multiple reaction monitoring (MRM) technique was used to monitor the ion transitions. The $\mathrm{m} / \mathrm{z}$ transition ions for VAL $355.100 \rightarrow 152.100$, GAN $256.100 \rightarrow 152.100$, VAL-D5 $360.100 \rightarrow 152.100$ and GAN-D5 $261.100 \rightarrow 152.100$ (Table 1, fig. 1a and 1b). After MRM finalization,
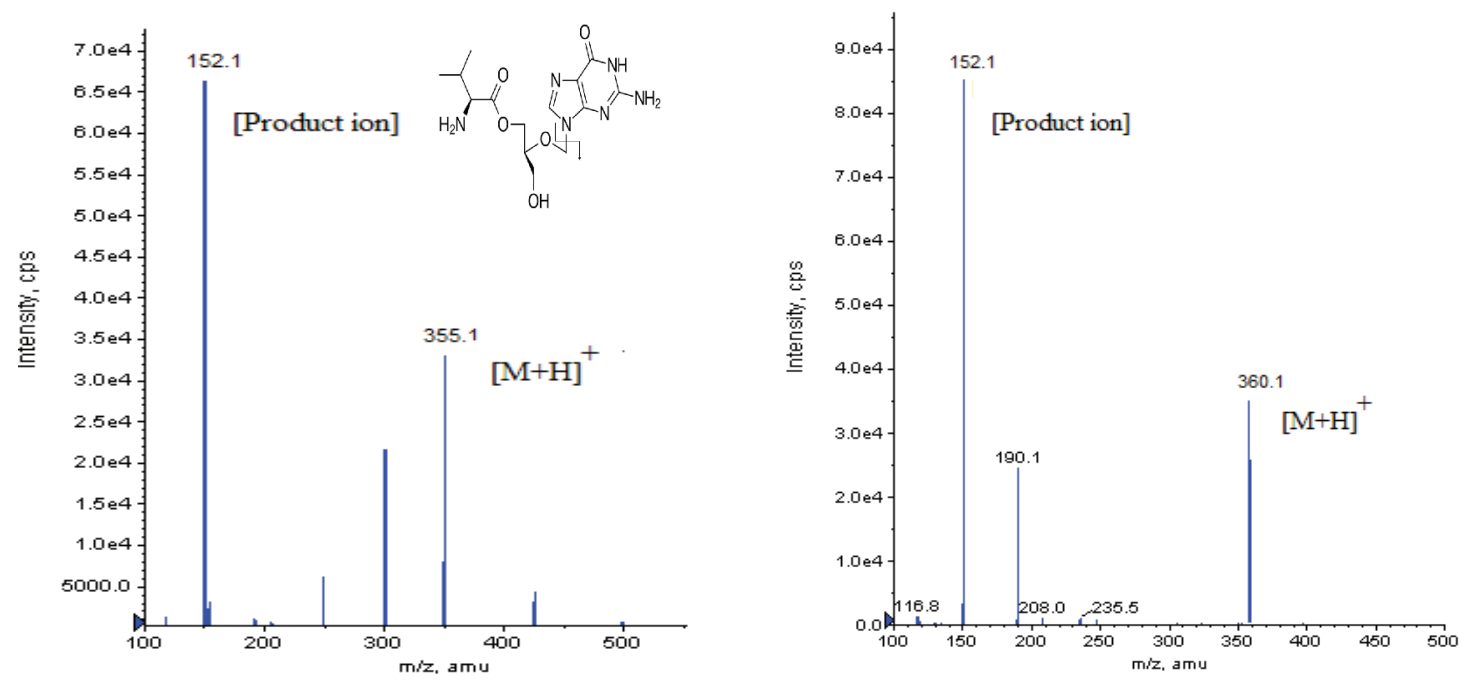

A

B
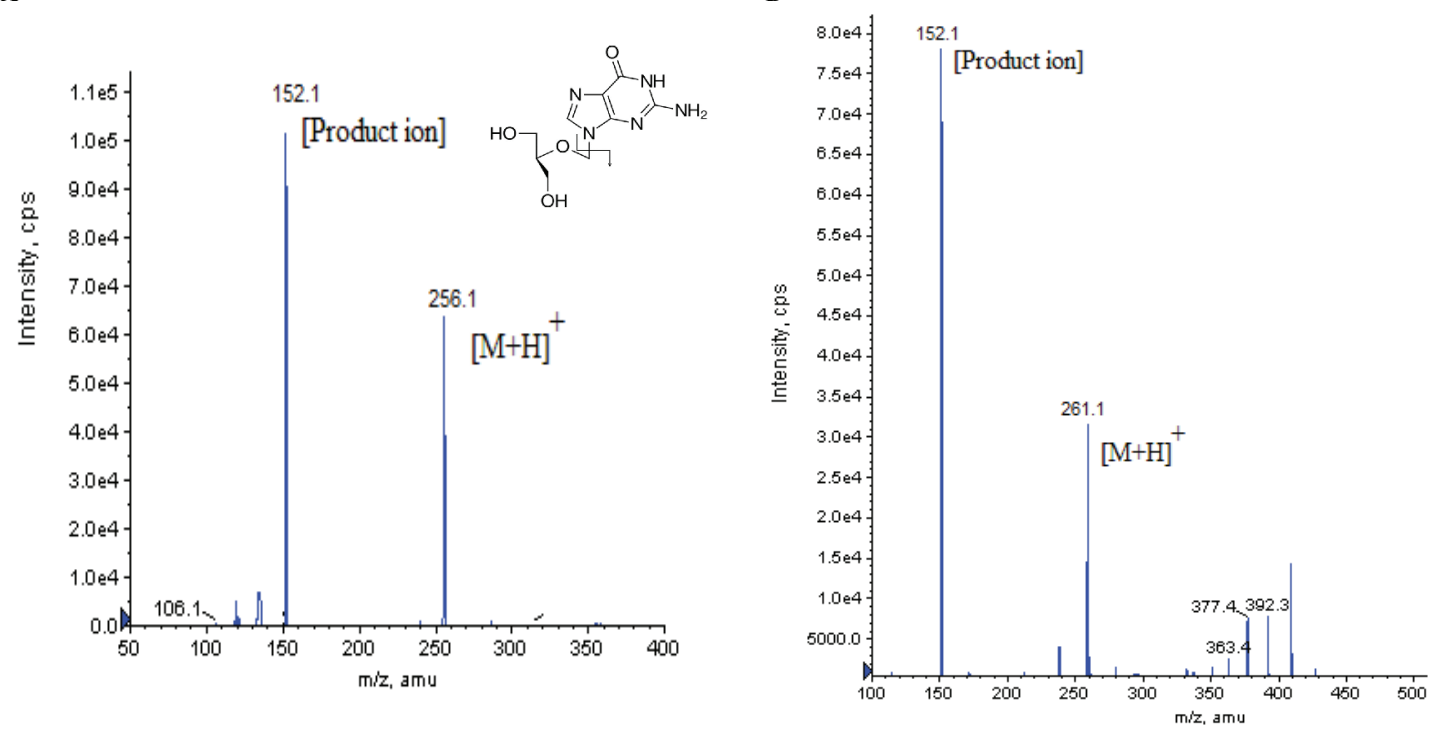

Fig. 1: Mass transition ions spectra of valganciclovir and ganciclovir A. valganciclovir, B. valganciclovir D5, C. ganciclovir and D. ganciclovir D5 
different mobile phases were used like combinations of methanol, ACN with buffer (ammonium acetate, ammonium formate, formic acid) additions and $\mathrm{pH}$ adjustments and columns of different make like C18, C8, phenyl of Kromosil, Agilent, Thermo Scientific, Zodiac, ACE 5 Phenyl for separation of VAL and GAN. The good peak shape, consistency and reproducibility was observed in mobile phase i.e. 35:65 (v/v) ratio of $10 \mathrm{mM}$ ammonium acetate in $0.3 \%$ formic acid and ACN with XDB Phenyl $(75 \mathrm{~mm} \times 4.6 \mu)$ at flow rate of $0.60 \mathrm{ml} / \mathrm{min}$ (Table 3 ).

After optimization of LC-MS/MS method, different extractive methods like SPE, protein precipitation (PPT) and liquid-liquid extraction (LLE) were used to extract drugs (VAL and GAN) from plasma. The SPE procedure gave better results compared to LLE and PPT, which could be that VAL and GAN were not completely extractable in LLE and PPT due to plasma binding. VAL is prodrug to GAN, the $2 \%$ OPA treatment would remove the acidic impurities and may stop the conversion of VAL to GAN in plasma and then $5 \%$ methanol treatment would remove impurities and may increases the un-ionization of GAN i.e. the MCX cartridges mechanism played an important role in maximum retention of acidic VAL and basic GAN in SPE method.

The carryover test is very important to know the sample passing from previous sample to next sample in any analysis either from higher or lower concentrations. No carryover was observed in extracted blanks $(n=6)$ after injection of 6 extracted LLOQ $(2.04 \mathrm{ng} / \mathrm{ml}$ of VAL; $40.41 \mathrm{ng} / \mathrm{ml}$ of GAN) and ULOQ (805.35 ng/ml of VAL and $12097.57 \mathrm{ng} / \mathrm{ml}$ of GAN) before every injection of blank. Background interference for VAL, GAN and ISs were tested by extracting $(n=10)$ blank plasma and found that there was no significant interference at RT of VAL, GAN and ISs (fig. 2) i.e. as per US FDA guidelines it was $<20 \%$ for analyte and $<5 \%$ for IS.

TABLE 3: EFFECT OF THE ABSENCE AND PRESENCE OF MATRIX ON VALGANCICLOVIR AND GANCICLOVIR

\begin{tabular}{|c|c|c|c|c|}
\hline \multirow{2}{*}{$\begin{array}{l}\text { Name of the } \\
\text { analyte }\end{array}$} & \multicolumn{2}{|c|}{$\begin{array}{c}\text { Absence of } \\
\text { matrix }\end{array}$} & \multicolumn{2}{|c|}{$\begin{array}{c}\text { Presence of matrix } \\
\text { (IS normalized matrix factor) }\end{array}$} \\
\hline & LQC & HQC & LQC & HQC \\
\hline Valganciclovir & $0.02^{\#}$ & $1.74^{\#}$ & $\begin{array}{c}0.98 \pm 0.02^{*} \\
(2.04)\end{array}$ & $\begin{array}{c}0.99 \pm 0.02^{*} \\
(1.68)\end{array}$ \\
\hline Ganciclovir & $0.05^{\#}$ & $4.35^{\#}$ & $\begin{array}{l}0.92 \pm 0.04^{*} \\
(3.98)\end{array}$ & $\begin{array}{l}0.93 \pm 0.02^{*} \\
(1.68)\end{array}$ \\
\hline
\end{tabular}

\#Mean area ratio $(\mathrm{n}=6)$; *mean \pm SD (\% CV) ISNF $(\mathrm{n}=10)$
Fig. 2: MRM spectra of valganciclovir and ganciclovir of blank plasma samples

A. blank-valganciclovir, B. blank-valganciclovir D5, C. blankganciclovir and D. blank-ganciclovir D5

The LLOQ level for CC of VAL $(2.04 \mathrm{ng} / \mathrm{ml})$ and GAN $(40.41 \mathrm{ng} / \mathrm{ml})$ in plasma were successfully quantified with precision and accuracy $7.49 \%$ and $101.23 \%$ for VAL and $3.52 \%$ and $101.19 \%$ for GAN (fig. 3).

ME was tested for the VAL and GAN using selected matrix lots $(n=10)$ at LQC and HQC levels and the results indicated no significant $\mathrm{ME}$ on analyte. $\mathrm{T}$ he mean IS matrix normalized factor (IS NMF) for VAL, GAN were $0.98,0.92$ at LQC and 0.99 and 0.99 at HQC levels. The precision for IS NMF for VAL and GAN were 2.04, $3.98 \%$ at LQC level and 1.68 and $1.68 \%$ at $\mathrm{HQC}$ level (IS NMF= peak response area ratio in presence of matrix ions/mean peak response area ratio in absence of matrix ions).

Different independent batches $(\mathrm{n}=5)$ were analysed on different days, each batch with zero blank, $10 \mathrm{CC}$ points and 6 replicates of LLOQ, LQC, MQC1, MQC2 and HQC. The concentration ranges for VAL was 2.04 to $805.35 \mathrm{ng} / \mathrm{ml}$ and GAL was 40.41 to $12097.57 \mathrm{ng} / \mathrm{ml}$. The correlation co-efficient (r) for each batch was $>0.99$ (fig. 4). The intraday $(n=12)$ and inter day $(n=30)$ accuracy and precision were within the 

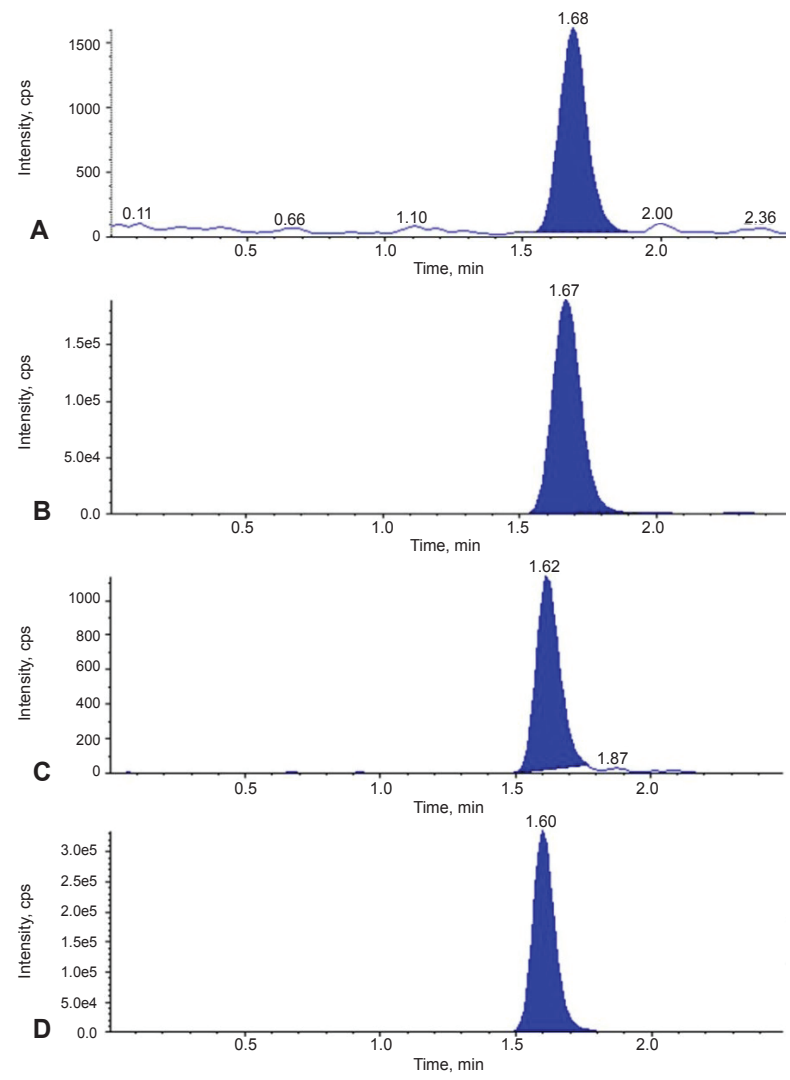

Fig. 3: MRM spectra of valganciclovir and ganciclovir at LLOQ levels

A. LLOQ-1-valganciclovir, B. LLOQ-1-valganciclovir D5, C. LLOQ QC-01-ganciclovir and D. LLOQ QC-01-ganciclovir D5 limits as per regulatory guidelines for VAL and GAN (Table 4). Recovery of VAL and GAN from spiked samples (extracted samples) was at LQC, MQC2 and HQC levels with their aqueous samples (non-

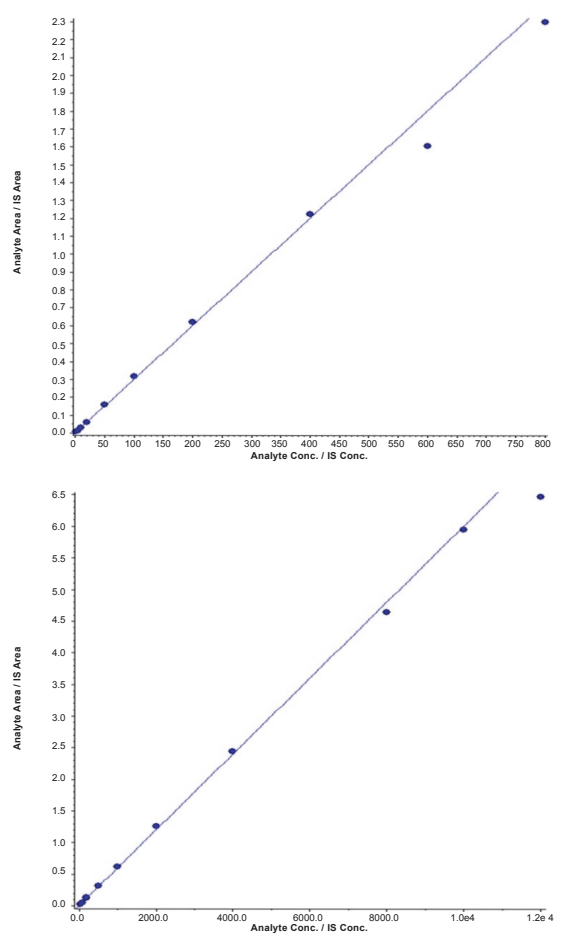

Fig. 4: Concentration-response linearity curves of valganciclovir and ganciclovir

TABLE 4: INTRA DAY AND INTER DAY ACCURACY AND PRECISION OF VALGANCICLOVIR AND GANCICLOVIR

\begin{tabular}{|c|c|c|c|c|c|}
\hline $\begin{array}{l}\text { Name of the } \\
\text { analyte }\end{array}$ & $\begin{array}{l}\text { Nominal concentration } \\
(\mathrm{ng} / \mathrm{ml})\end{array}$ & Mean (SD) & $\begin{array}{c}\text { Precision } \\
(\% \mathrm{CV})\end{array}$ & $\begin{array}{l}\text { \% Accuracy } \\
\text { Mean (SD) }\end{array}$ & $\begin{array}{l}\text { Precision } \\
\text { (\%CV) }\end{array}$ \\
\hline \multicolumn{6}{|c|}{ Intraday accuracy and precision $(n=12)$} \\
\hline & LLOQ QC (2.04) & $1.86(0.23)$ & 11.88 & $94.66(9.23)$ & 9.75 \\
\hline & LQC $(6.01)$ & $6.05(0.28)$ & 4.70 & $100.56(4.73)$ & 4.71 \\
\hline \multirow[t]{5}{*}{ Valganciclovir } & MQC1 (125.28) & $134.958(5.07)$ & 3.75 & $107.73(4.04)$ & 3.75 \\
\hline & MQC2 (377.35) & $406.96(7.63)$ & 1.88 & $107.84(2.02)$ & 1.88 \\
\hline & HQC (566.56) & $608.80(19.02)$ & 3.12 & $107.44(3.36)$ & 3.12 \\
\hline & LLOQ QC (40.43) & $41.89(2.66)$ & 6.36 & $103.62(6.59)$ & 6.36 \\
\hline & LQC (121.04) & $117.53(2.38)$ & 2.03 & $97.10(1.97)$ & 2.03 \\
\hline \multirow[t]{3}{*}{ Ganciclovir } & MQC1 (1806.56) & $1782.99(54.43)$ & 3.05 & $98.69(3.01)$ & 3.05 \\
\hline & MQC2 (6021.89) & 6029.31 (181.87) & 3.02 & $100.12(3.02)$ & 3.02 \\
\hline & HQC (9041.88) & $8799.88(320.43)$ & 3.64 & $97.32(3.54)$ & 3.64 \\
\hline \multicolumn{6}{|c|}{ Inter day accuracy and precision $(n=30)$} \\
\hline \multirow{5}{*}{ Valganciclovir } & LLOQ QC (2.04) & $2.02(0.21)$ & 10.43 & $98.97(10.32)$ & 10.43 \\
\hline & LQC (6.01) & $5.91(0.37)$ & 6.30 & $98.25(6.19)$ & 6.30 \\
\hline & MQC1 (125.28) & $134.845(3.57)$ & 2.65 & $107.635(2.85)$ & 2.65 \\
\hline & MQC2 (377.35) & $401.60(8.64)$ & 2.15 & $106.43(2.29)$ & 2.15 \\
\hline & HQC (566.56) & $592.86(20.12)$ & 3.39 & $104.63(3.55)$ & 3.39 \\
\hline \multirow{5}{*}{ Ganciclovir } & LLOQ QC (40.43) & $41.38(2.74)$ & 6.63 & $102.35(6.78)$ & 6.63 \\
\hline & LQC (121.04) & $115.42(3.54)$ & 3.06 & $95.35(2.92)$ & 3.06 \\
\hline & MQC1 (1806.56) & $1711.818(77.53)$ & 4.53 & 94.75 (4.29) & 4.53 \\
\hline & MOC2 (6021.89) & $5918.88(167.46)$ & 2.83 & $98.28(2.78)$ & 2.83 \\
\hline & HQC (9041.88) & $8761.30(240.47)$ & 2.74 & $96.89(2.66)$ & 2.74 \\
\hline
\end{tabular}


extracted samples). SPE gave almost clean extractive of VAL with $90.91 \%$ and GAN with $93.86 \%$ recovery (Table 5).

The results of the DI at 25:75 of VAL and GAN (2495.07 $\mathrm{ng} / \mathrm{ml}$ of VAL and $38205.11 \mathrm{ng} / \mathrm{ml}$ of GAN) were analysed as 6 replicates, which were found to be within the acceptance criteria with precision (1.27) and accuracy $(100.08 \%)$ to VAL and precision (1.04) and accuracy $(108.05 \%)$ to GAN and the processed sample have nominal concentration within $\pm 15 \%$.

Stability of VAL and GAN was studied under diverse conditions and the results are summarized in Table 6 . VAL and GAN stock solutions were stable at RT for $21 \mathrm{~h}$ and spiking samples (bench-top stability) stable at RT for $10 \mathrm{~h}$. The spiked storage samples at $-70^{\circ}$ were found to be stable after 4 freeze-thaw cycles. VAL and GAN were stable after the processing i.e. wet extract stability at RT and AS at $5^{\circ}$ were $51 \mathrm{~h}$ and $63 \mathrm{~h}$, respectively. The re-injection stability for the processed sample was $41 \mathrm{~h}$. All the tested conditions for VAL and GAN stability of their CCs and QCs were within the acceptance criteria $( \pm 15 \%$ of their nominal concentration).

The integrity of a validated method on long run of study sample analysis was evaluated on long run by processing 40 replicates of LQC, MQC1, MQC2 and HQC samples with freshly prepared CC samples and 6 replicates of each QC samples as total of 192 samples

TABLE 5: RECOVERY OF VALGANCICLOVIR, GANCICLOVIR AND VALGANCICLOVIR D5, GANCICLOVIR D5 FROM SPIKED PLASMA SAMPLES

\begin{tabular}{|c|c|c|c|c|c|c|}
\hline & \multicolumn{2}{|c|}{ LQC\# response } & \multicolumn{2}{|c|}{ MQC2\# response } & \multicolumn{2}{|c|}{$\mathrm{HQC}^{\#}$ response } \\
\hline & Extracted & Non-extracted & Extracted & Non-extracted & Extracted & Non-extracted \\
\hline \multicolumn{7}{|l|}{ Valganciclovir } \\
\hline Mean & 26922.0 & 30504.2 & 2086635.0 & 2123642.8 & 2611220.8 & 3028957.8 \\
\hline S.D. & 562.32 & 1208.88 & 36349.68 & 78870.33 & 69648.25 & 78196.84 \\
\hline C.V (\%) & 2.09 & 3.96 & 1.74 & 3.71 & 2.67 & 2.58 \\
\hline \% Recovery & 88.26 & & 98.26 & & 86.21 & \\
\hline Overall recovery & $90.91 \%$ & & & & & \\
\hline \multicolumn{7}{|l|}{ Ganciclovir } \\
\hline Mean & 45327.0 & 48604.7 & 2261993.7 & 2488342.2 & 3887515.3 & 3990304.5 \\
\hline S.D. & 824.02 & 1580.09 & 59409.29 & 55741.90 & 66063.77 & 133590.62 \\
\hline C.V.(\%) & 1.82 & 3.25 & 2.63 & 2.24 & 1.70 & 3.35 \\
\hline \% Recovery & 93.26 & & 90.90 & & 97.42 & \\
\hline Overall recovery & & & $93.86 \%$ & & & \\
\hline
\end{tabular}

TABLE 6: STABILITY OF VALGANCICLOVIR AND GANCICLOVIR AT DIFFERENT CONDITIONS

\begin{tabular}{|c|c|c|c|c|}
\hline \multirow{3}{*}{$\begin{array}{l}\text { Name of the stability } \\
\text { parameter }\end{array}$} & \multicolumn{2}{|c|}{ Valganciclovir } & \multicolumn{2}{|c|}{ Ganciclovir } \\
\hline & $\begin{array}{c}\text { LQC } \\
(6.01 \mathrm{ng} / \mathrm{ml})\end{array}$ & $\begin{array}{c}\text { HQC } \\
(566.59 \mathrm{ng} / \mathrm{ml})\end{array}$ & $\begin{array}{c}\text { LQC } \\
(121.04 \mathrm{ng} / \mathrm{ml})\end{array}$ & $\mathrm{C}$ \\
\hline & \multicolumn{2}{|c|}{$\begin{array}{c}\text { mean } \pm \text { SD }(\% \mathrm{CV}) \\
(\% \text { nominal concentration) }\end{array}$} & \multicolumn{2}{|c|}{$\begin{array}{c}\text { mean } \pm \text { SD (\% CV) } \\
(\% \text { nominal concentration) }\end{array}$} \\
\hline $\begin{array}{l}\text { Freeze thaw } \\
\text { (4 cycles) }\end{array}$ & $\begin{array}{c}5.61 \pm 5.60 \\
(4.57)(93.22)\end{array}$ & $\begin{array}{l}562.53 \pm 17.49 \\
(3.11)(99.28)\end{array}$ & $\begin{array}{l}116.60 \pm 9.75 \\
(8.36)(96.33)\end{array}$ & $\begin{array}{l}9774.28 \pm 579.76 \\
(6.12)(108.10)\end{array}$ \\
\hline $\begin{array}{l}\text { Bench top at RT } \\
\text { (10 h } 26 \mathrm{~min})\end{array}$ & $\begin{array}{c}5.88 \pm 0.21 \\
(3.72)(97.77)\end{array}$ & $\begin{array}{c}587.97 \pm 8.79 \\
(1.50)(103.77)\end{array}$ & $\begin{array}{c}125.18 \pm 1.88 \\
(1.50)(103.42)\end{array}$ & $\begin{array}{l}8751.63 \pm 365.62 \\
(4.18)(96.79)\end{array}$ \\
\hline $\begin{array}{l}\text { Short term } \\
\left(-20 \pm 5^{\circ}\right) \\
(2 \mathrm{~d} 21 \mathrm{~h})\end{array}$ & $\begin{array}{c}5.39 \pm 0.33 \\
(6.13)(89.61)\end{array}$ & $\begin{array}{l}564.86 \pm 26.16 \\
(4.63)(99.69)\end{array}$ & $\begin{array}{c}118.87 \pm 8.88 \\
(7.47)(98.21)\end{array}$ & $\begin{array}{c}9983.81 \pm 166.21 \\
(1.66)(110.42)\end{array}$ \\
\hline $\begin{array}{l}\text { Wet extract at RT } \\
(51 \mathrm{~h} 41 \mathrm{~min})\end{array}$ & $\begin{array}{c}5.75 \pm 0.13 \\
(2.27)(95.57)\end{array}$ & $\begin{array}{l}562.69 \pm 12.34 \\
(2.19)(99.31)\end{array}$ & $\begin{array}{c}122.55 \pm 6.47 \\
(5.28)(101.25)\end{array}$ & $\begin{array}{l}9043.98 \pm 760.46 \\
(8.41)(100.02)\end{array}$ \\
\hline $\begin{array}{l}\text { Auto sampler at } 5^{\circ} \\
(63 \mathrm{~h} 2 \mathrm{~min})\end{array}$ & $\begin{array}{c}5.43 \pm 0.22 \\
(4.18)(90.30)\end{array}$ & $\begin{array}{l}563.07 \pm 16.43 \\
(2.12)(99.38)\end{array}$ & $\begin{array}{c}115.82 \pm 14.0 \\
(12.1)(95.69)\end{array}$ & $\begin{array}{r}9681.70 \pm 299.27 \\
(3.09)(107.08)\end{array}$ \\
\hline $\begin{array}{l}\text { Re-injection } \\
\text { ( } 41 \text { h } 31 \text { min) }\end{array}$ & $\begin{array}{c}5.84 \pm 0.47 \\
(8.16)(97.06)\end{array}$ & $\begin{array}{c}606.30 \pm 4.38 \\
(0.72)(107.01)\end{array}$ & $\begin{array}{l}105.71 \pm 5.49 \\
(5.20)(87.34)\end{array}$ & $\begin{array}{c}8898.27 \pm 174.16 \\
(1.96)(98.41)\end{array}$ \\
\hline
\end{tabular}

RT means room temperature; \% nominal concentration is the mean concentration of stability LQC or HQC samplesxnominal concentration of freshly prepared LQC or HQC $\times 100$. Mean concentration of freshly prepared LQC or HQC samples $\times$ nominal concentration of stability LQC or HQC 
were analysed as single batch. All the processed samples were within the acceptance criteria as their nominal concentration was $\pm 15 \%$ at each QC level.

The validated method was successfully applied to a clinical study on healthy human volunteers $(n=6)$ with $50 \mathrm{mg} / \mathrm{ml}$ of $900 \mathrm{mg}$ oral solution dosage at fasting condition. The mean results of drug concentration versus time are shown in fig 5a (VAL) and 5b (GAN). The maximum concentration $\left(\mathrm{C}_{\max }\right)$ of VAL was about $300 \mathrm{ng} / \mathrm{ml}$ at maximum time $\left(\mathrm{T}_{\max }\right) 0.50 \mathrm{~h}$ and $\mathrm{C}_{\max }$

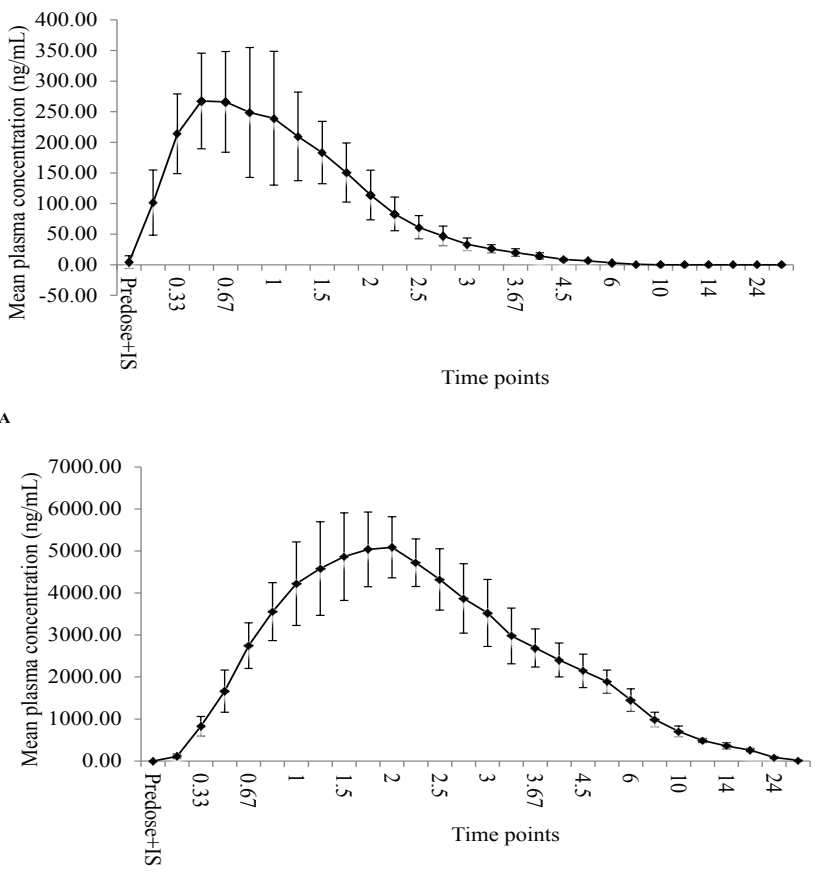

Fig. 5: Plasma concentration vs. time profile of valganciclovir and ganciclovir

Mean concentration of $A$. valganciclovir and B. ganciclovir from clinical samples was plotted against time (-४ -$)$ of GAN was about $5000 \mathrm{ng} / \mathrm{ml}$ at $\mathrm{T}_{\max } 1.00 \mathrm{~h}$. The pharmacokinetic parameters were summarized in Table 7. After the study sample analysis, ISR was also carried out because it is important to know the reproducibility of concentration vs. time and is necessary for the approval of drugs by USFDA. The performed ISR analysis samples were within the acceptance $(<20 \%)$ variation from their initial values (Table 8).

Bioanalysis plays a key role in the drug discovery process by providing reliable pharmacokinetic parameters by estimating the test drug concentrations in biological matrices like blood, plasma, and urine ${ }^{[23,24]}$. Currently the situation of emerging and resistant diseases is prompting the researchers to discover lead drug molecules with broad therapeutic values. These discoveries simultaneously require reliable analytical methods with rapid analysis and accuracy. HIV is most mortality causing disease in the world from mid-20th century and researchers developed few drugs to control the disease and its side effects but till now there is no drug to cure HIV/AIDS. VAL is one of the antiviral drugs effective against CMV infections in HIV/AIDS patients and also used to control CMV infections in organ transplantation condition. VAL is a prodrug

TABLE 7: PHARMACOKINETIC PARAMETERS OF VALGANCICLOVIR AND GANCICLOVIR

\begin{tabular}{lcc}
\hline $\begin{array}{l}\text { Pharmacokinetic } \\
\text { parameter }\end{array}$ & $\begin{array}{c}\text { Valganciclovir } \\
(\text { mean } \pm \text { SD) }\end{array}$ & $\begin{array}{c}\text { Ganciclovir } \\
(\text { mean } \pm \text { SD) }\end{array}$ \\
\hline C-max $(\mathrm{ng} / \mathrm{ml})$ & $303.48 \pm 85.15$ & $5193.53 \pm 832.68$ \\
T-max $(\mathrm{h})$ & $0.85 \pm 0.47$ & $1.71 \pm 0.29$ \\
AUC-T $(\mathrm{h} \times \mathrm{ng} / \mathrm{ml})$ & $498.07 \pm 80.54$ & $26422.75 \pm 4462.74$ \\
AUC-INF $(\mathrm{h} \times \mathrm{ng} / \mathrm{ml})$ & $498.53 \pm 80.42$ & $26549.92 \pm 4486.83$ \\
T-half $(\mathrm{h})$ & $1.14 \pm 0.40$ & $4.97 \pm 0.84$ \\
K-el $(1 / \mathrm{h})$ & $0.66 \pm 0.18$ & $0.14 \pm 0.02$ \\
\hline
\end{tabular}

TABLE 8: ANALYSIS OF VALGANCICLOVIR AND GANCICLOVIR IN SUBJECT SAMPLES

\begin{tabular}{|c|c|c|c|c|c|c|c|}
\hline \multicolumn{4}{|c|}{ Valganciclovir } & \multicolumn{4}{|c|}{ Ganciclovir } \\
\hline $\begin{array}{l}\text { Sample } \\
\text { ID" (h) }\end{array}$ & $\begin{array}{l}\text { Initial concent- } \\
\text { ration }(\mathrm{ng} / \mathrm{ml})\end{array}$ & $\begin{array}{c}\text { ISR Concentration } \\
(\mathrm{ng} / \mathrm{ml})\end{array}$ & $\begin{array}{c}\% \\
\text { Variability }\end{array}$ & $\begin{array}{l}\text { Sample } \\
\text { ID (h) }\end{array}$ & $\begin{array}{l}\text { Initial concentration } \\
(\mathrm{ng} / \mathrm{ml})\end{array}$ & $\begin{array}{c}\text { ISR concentration } \\
(\mathrm{ng} / \mathrm{ml})\end{array}$ & $\begin{array}{c}\% \\
\text { Variability }\end{array}$ \\
\hline 0.83 & 442.70 & 390.25 & 12.59 & 2.25 & 4155.89 & 4000.15 & 4078.02 \\
\hline 4.50 & 7.550 & 7.12 & 5.85 & 16.00 & 226.18 & 198.562 & 212.372 \\
\hline 0.83 & 312.56 & 298.54 & 4.59 & 1.75 & 4440.41 & 4215.85 & 4328.13 \\
\hline 5.00 & 8.979 & 7.95 & 12.06 & 16.00 & 251.94 & 225.369 & 238.65 \\
\hline 2.00 & 192.53 & 186.14 & 3.38 & 2.00 & 5516.79 & 5001.99 & 5259.39 \\
\hline 5.00 & 8.595 & 7.56 & 12.76 & 16.00 & 260.21 & 245.698 & 252.95 \\
\hline 0.67 & 307.19 & 287.98 & 6.46 & 2.00 & 4380.02 & 4100.66 & 4240.34 \\
\hline 4.00 & 10.97 & 9.58 & 13.54 & 16.00 & 254.85 & 232.61 & 243.73 \\
\hline 0.67 & 214.63 & 200.01 & 7.06 & 1.50 & 6364.85 & 6102.75 & 6233.79 \\
\hline 4.00 & 9.67 & 8.95 & 7.73 & 24.00 & 124.58 & 119.258 & 121.92 \\
\hline 0.50 & 203.67 & 198.56 & 2.54 & 2.00 & 5636.15 & 5512.4 & 5574.27 \\
\hline 4.50 & 9.10 & 8.95 & 1.72 & 16.00 & 226.76 & 217.951 & 222.35 \\
\hline
\end{tabular}

"Represents individual time point 
of GAN, which inhibits the chain elongation of viral replication $^{[13]}$. Since the WHO declared VAL as an essential medicine ${ }^{[14]}$ and that VAL received generic approval, it became very essential that fast and reliable methods are available to quantify VAL and GAN in different biological matrices from generic formulations under development to get marketing approval. In an attempt to fill this gap, the current study was taken up to develop a simple and rugged method to evaluate VAL and GAN simultaneously in human plasma, validate it as per USFDA guidelines and to apply this method to determine pharmacokinetic parameters of VAL and GAN.

The developed and validated method is the first method which used deuterated compounds as ISs. Because ISs are very important to obtain high accuracy when LC is coupled with a mass detector and stable isotopelabelled (stable ISs) drugs as ISs help to find possible $\mathrm{ME}^{[25]}$. The earlier reported methods for VAL and GAN used non-isotope drugs as ISs ${ }^{[17,18]}$. The validated method is found to have very high sensitivity, since the method facilitated quantification of VAL and GAN at $2 \mathrm{ng} / \mathrm{ml}$ and $40 \mathrm{ng} / \mathrm{ml}$, respectively with high recovery $(>90 \%)$ and low runtime making this method an economic and easy to run method compared to other reported methods ${ }^{[16,19]}$. The developed and validated method using deuterated IS was found reliable and could be successfully applied to a clinical study to estimate VAL and GAN in human plasma samples quite effectively.

\section{Acknowledgments:}

The authors thank AnaCipher CRO, Hyderabad for providing the necessary facilities to complete the research work.

\section{Conflict of interest:}

Authors declare no conflicts of interest.

\section{REFERENCES}

1. Hughes JP, Rees S, Kalindjian SB, Philpott KL. Principles of early drug discovery. Br J Pharmacol 2011;162:1239-49.

2. Mohs RC, Greig NH. Drug discovery and development: Role of basic biological research. Alzheimer's Dement 2017;3:651-7.

3. Akhondzadeh S. The Importance of Clinical Trials in Drug Development. Avicenna J Med Biotechnol 2016;8:151.

4. Jasovský D, Littmann J, Zorzet A, Cars O. Antimicrobial resistance-a threat to the world's sustainable development. Ups J Med Sci 2016;121:159-64.

5. Fair RJ, Tor Y. Antibiotics and bacterial resistance in the $21 \mathrm{st}$ century. Perspect Medicin Chem 2014;6:25-64.
6. Moellering RC Jr. Discovering new antimicrobial agents. Int J Antimicrob Agents. 2011;37:2-9.

7. Howard CR, Fletcher NF. Emerging virus diseases: can we ever expect the unexpected? Emerg Microbes Infect 2012;1(12):e46.

8. Sarma N. Emerging and Re-emerging Infectious Diseases in South East Asia. Indian J Dermatol 2017;62:451-5.

9. Martin DF, Sierra-Madero J, Walmsley S, Wolitz RA, Macey $\mathrm{K}$, Georgiou $\mathrm{P}$, et al. A controlled trial of valganciclovir as induction therapy for cytomegalovirus retinitis. N Engl J Med 2002;346:1119-26.

10. Boeckh M, Nichols WG, Chemaly RF, Papanicolaou GA, Wingard JR, Xie H, et al. Valganciclovir for the prevention of complications of late cytomegalovirus infection after allogeneic hematopoietic cell transplantation: a randomized trial. Ann Inter Med 2015;162:1-10.

11. Tan BH. Cytomegalovirus Treatment. Curr Treat Options Infect Dis 2014;6(3):256-70.

12. Chen H, Beardsley GP, Coen DM. Mechanism of ganciclovirinduced chain termination revealed by resistant viral polymerase mutants with reduced exonuclease activity. Proc Natl Acad Sci USA 2014;111:17462-7.

13. Lukacova V, Goelzer P, Reddy M, Greig G, Reigner B, Parrott N. A physiologically based pharmacokinetic model for ganciclovir and its prodrug valganciclovir in adults and children. AAPS J 2016;18:1453-63.

14. Matthews T, Boehme R. Antiviral activity and mechanism of action of ganciclovir. Rev Infect Dis 2016;10 Suppl 3:S490-4.

15. WHO Model List of Essential Medicines (19th List). World Health Organization. April 2015. Available from: https:// www.who.int/medicines/publications/essentialmedicines/en/.

16. Rigo-Bonnin R, Padullés A, Corral-Comesaña S, Cerezo G, Grinyó JM, Colom H, et al. Measurement of ganciclovir concentration in human plasma by ultra-performance liquid chromatography-tandem mass spectrometry. Clin Chimica Acta 2014;427:58-64.

17. Heinig K, Wirz T, Gajate-Perez A, Belli S. Determination of Ganciclovir and its prodrug Valganciclovir by hydrophilic interaction liquid chromatography-tandem mass spectrometry. J Chromatogr B Analyt Technol Biomed Life Sci 2011;879:436-42.

18. Yadav M, Upadhyay V, Singhal P, Goswami S, Shrivastav PS. Stability evaluation and sensitive determination of antiviral drug, valacyclovir and its metabolite acyclovir in human plasma by a rapid liquid chromatography-tandem mass spectrometry method. J Chromatogr B AnalytTechnol Biomed Life Sci 2009;877:680-8.

19. Xu HR, Li XN, Chen WL, Liu GY, Chu NN, Yu C. A sensitive assay for simultaneous determination of plasma concentrations of valganciclovir and its active metabolite ganciclovir by LC/MS/MS. J Chromatogr B Analyt Technol Biomed Life Sci 2007;848:329-34.

20. Chokkathukalam A, Kim DH, Barrett MP, Breitling R, Creek DJ. Stable isotope-labeling studies in metabolomics: new insights into structure and dynamics of metabolic networks. Bioanalysis 2014;6:511-24.

21. Nageswara RR. Stable Labeled Isotopes as Internal Standards: A Critical Review. Mod Appl Pharm Pharmacol 2017;1:1-4.

22. Guidance for Industry, Bioanalytical Method Validation, U.S. Department of Health and Human Services, Food and Drug Administration, Center for Drug Evaluation and Research (CDER), Center for Veterinary Medicine (CMV), May 2018. 
Available from: https://www.fda.gov/files/drugs/published/ Bioanalytical-Method-Validation-Guidance-for-Industry.pdf.

23. González O, Blanco ME, Iriarte G, Bartolome L, Maguregui MI, Alonso RM, et al. Bioanalytical chromatographic method validation according to current regulations, with a special focus on the non-well defined parameters limit of quantification, robustness and matrix effect. J Chromatogr A 2014;1353:10-27.
24. Novakova L, Vlckova H. A review of current trends and advances in modern bioanalytical methods: chromatography and sample preparation. Anal Chim Acta 2009;656;8-35.

25. Stokvis E, Rosing H, Beijnen JH. Stable isotopically labeled internal standards in quantitative bioanalysis using liquid chromatography/mass spectrometry: necessity or not? Rapid Commun Mass Spectrom 2005;19:401-7. 